Marquette University

e-Publications@Marquette

5-3-2003

\title{
Kinetic and Spectroscopic Characterization of the H178A Methionyl Aminopeptidase from Escherichia coli
}

\author{
Alicja J. Copik \\ Utah State University \\ Sabina I. Swierczek \\ Utah State University \\ W. Todd Lowther \\ University of Oregon \\ Ventris M. D'Souza \\ Utah State University \\ Brian W. Matthews \\ University of Oregon
}

See next page for additional authors

Follow this and additional works at: https://epublications.marquette.edu/chem_fac

Part of the Chemistry Commons

\section{Recommended Citation}

Copik, Alicja J.; Swierczek, Sabina I.; Lowther, W. Todd; D'Souza, Ventris M.; Matthews, Brian W.; and Holz, Richard C., "Kinetic and Spectroscopic Characterization of the H178A Methionyl Aminopeptidase from Escherichia coli" (2003). Chemistry Faculty Research and Publications. 315.

https://epublications.marquette.edu/chem_fac/315 


\section{Authors}

Alicja J. Copik, Sabina I. Swierczek, W. Todd Lowther, Ventris M. D'Souza, Brian W. Matthews, and Richard C. Holz 
Marquette University

\title{
e-Publications@Marquette
}

\section{Chemistry Faculty Research and Publications/College of Arts and Sciences}

This paper is NOT THE PUBLISHED VERSION; but the author's final, peer-reviewed manuscript. The published version may be accessed by following the link in th citation below.

Biochemistry, Vol. 42, No. 20 (2003): 6283-6292. DOI. This article is (C) American Chemical Society and permission has been granted for this version to appear in e-Publications@Marquette. American Chemical Society does not grant permission for this article to be further copied/distributed or hosted elsewhere without the express permission from American Chemical Society.

\section{Kinetic and Spectroscopic Characterization of the H178A Methionyl Aminopeptidase from Escherichia coli}

\author{
Alicja J. Copik \\ Sabina I. Swierczek \\ W. Todd Lowther \\ Ventris M. D'souza \\ Brian W. Matthews \\ Richard C. Holz \\ Department of Chemistry and Biochemistry, Utah State University, Logan, Utah 84322-0300 and The \\ Howard Hughes Medical Institute, Institute of Molecular Biology, University of Oregon, Eugene, Oregon \\ 97403
}

\section{Abstract}

To gain insight into the role of the strictly conserved histidine residue, H178, in the reaction mechanism of the methionyl aminopeptidase from Escherichia coli (EcMetAP-I), the H178A mutant enzyme was prepared. Metal-reconstituted H178A binds only one equivalent of $\mathrm{Co}(\mathrm{II})$ or Fe(II) tightly with affinities that are identical to the WT enzyme based on kinetic and isothermal titration calorimetry (ITC) data. Electronic absorption spectra of $\mathrm{Co}$ (II)-loaded H178A EcMetAP-I indicate that the active site divalent metal ion is pentacoordinate, identical to the WT enzyme. These data indicate that the metal binding site has not been affected by altering H178. The effect of altering H178 on activity is, in general, due to a decrease 
in $k_{\text {cat }}$ The $k_{\text {cat }}$ value for Co(II)-loaded H178A decreased 70-fold toward MGMM and 290-fold toward MP- $p$ NA compared to the WT enzyme, while $k_{\text {cat }}$ decreased 50-fold toward MGMM for the Fe(II)-loaded H178A enzyme and 140-fold toward MP- $p$-NA. The $K_{\mathrm{m}}$ values for MGMM remained unaffected, while those for MP$p$-NA increased approximately 2 -fold for Co(II)- and Fe(II)-loaded H178A. The $k_{\text {cat }} / K_{\mathrm{m}}$ values for both $\mathrm{Co}$ (II)- and Fe(II)-loaded H178A toward both substrates ranged from $\sim 50$ - to 580-fold reduction. The $\mathrm{pH}$ dependence of $\log K_{\mathrm{m}}, \log k_{\text {cat }}$ and $\log \left(k_{\text {cat }} / K_{\mathrm{m}}\right)$ of both WT and H178A $E c$ MetAP-I were also obtained and are identical, within error, for H178A and WT EcMetAP-I. Therefore, H178A is catalytically important but is not required for catalysis. Assignment of one of the observed $\mathrm{p} K_{\mathrm{a}}$ values at 8.1 for WT EcMetAP-I was obtained from plots of molar absorptivity at $\lambda_{\max (640)} \mathrm{VS} \mathrm{pH}$ for both WT and H178A EcMetAP-I. Apparent $\mathrm{p} K_{\mathrm{a}}$ values of 8.1 and 7.6 were obtained for WT and H178A EcMetAP-I, respectively, and were assigned to the deprotonation of a metal-bound water molecule. The data reported herein provide support for the key elements of the previously proposed mechanism and suggest that a similar mechanism can apply to the enzyme with a single metal in the active site.

Methionyl aminopeptidases (MetAPs) 1 represent a unique class of protease that is capable of removing an $\mathrm{N}$-terminal methionine residue from nascent polypeptide chains $(\underline{1-4})$. Since the biosynthesis of all prokaryotic and eukaryotic proteins present in the cytosol starts with the initiator methionine, MetAPs play a central role in protein synthesis. While the rationale for the removal of the initiator methionine remains unclear, several explanations have been proposed ( $\underline{5}$ ). Some involve the facilitation of further processing after excision of the N-terminal groups such as the removal of signal sequences if present, proteolytic cleavage to generate shorter peptides, and the covalent attachment of residues and blocking groups such as acetyl or myristoyl groups $(\underline{4})$. The structure of mature $\mathrm{N}$-termini play important roles in $\mathrm{N}$ directed degradation pathways and also in targeting of cellular membranes $(\underline{6,7})$. MetAPs are therefore one of the key cellular enzymes involved in protein maturation. The physiological importance of MetAP activity is underscored by the lethality upon the deletion of the MetAP gene in Escherichia coli, Salmonella typhimurium, and Saccharomyces cerevisiae $(\underline{8-11})$. Moreover, MetAPs have recently been identified as the molecular target for the epoxide-containing anti-angiogenesis agents ovalicin and fumagilin, one of which is in phase III clinical trials $(\underline{12-16})$. Therefore, MetAPs represent an important target for the development of anti-angiogenesis agents for cancer therapy as well as antibacterial and/or antifungal drugs $(\underline{17})$.

MetAPs are organized into two classes (types I and II) based on the absence or presence of an extra 62amino acid sequence (of unknown function) inserted near the catalytic domain. The type-I MetAP from $E$. coli (EcMetAP-I), and the type II MetAPs from Homo sapiens (HsMetAP-II) and Pyrococcus furiosus (PAMetAP-II) have been crystallographically characterized $(16,18-21)$. In all three structures, identical catalytic domains have been observed that contain a bis $(\mu$-carboxylato)( $\mu$-aquo/hydroxo)dicobalt core with an additional carboxylate residue at each metal site and a single histidine bound only to the first metal ion. Recently, it was suggested that the in vivo metal ion for EcMetAP-I is Fe(II), based on a combination of whole cell metal analyses and activity measurements as well as in vitro activity measurements and substrate binding constants $(\underline{22,23})$. In addition, the observed catalytic activity as a function of divalent metal ion concentration and the metal binding constants for both Fe(II) and Co(II) EcMetAP-I and PfMetAP-II led to the proposal that MetAPs function as mononuclear enzymes in vivo $(\underline{23}, 24)$. The high-affinity or catalytically relevant metal binding site was assigned as the histidinecontaining site by ${ }^{1} \mathrm{H}$ NMR spectroscopy $(\underline{23})$, which was recently verified by extended X-ray absorption fine structure (EXAFS) spectroscopy $(\underline{25})$.

A common feature among metalloproteases is an ionizable group within close proximity of the active site that functions as a general acid and/or base $(\underline{26-30})$. For example, in thermolysin $(\underline{26})$ and carboxypeptidase A ( $\underline{30})$, a glutamate is considered to play this role by assisting in the deprotonation of the metal bound water molecule. Within the active site of all MetAPs, three solvent molecules exist, the first of which bridges between the two cobalt ions, while a second is terminally ligated to Co2 $(16,18-21)$. A third solvent molecule bridges between an active site histidine residue, H178, and the water molecule that 
bridges between the two Co(II) ions. H178 is in close proximity to both cobalt ions (5.1 A from Co1 and 6.6 $\AA$ from Co2), and is strictly conserved among all MetAPs studied to date. Recent crystallographic studies on the transition-state analogue inhibitor, methionine phosphonate (l-MetP) bound to EcMetAP-I, revealed that a phosphonate oxygen atom bridges between Co1 and H178 (21). On the basis of these data, the catalytic role of $\mathrm{H} 178$ was proposed to be stabilization of the transition state $(\underline{20,31})$. Earlier studies on H178A EcMetAP-I showed that the variant has 50-fold lower activity as compared to wild-type EcMetAP-I (20). To gain insight into the role of H178 in the catalytic mechanism of N-terminal cleavage of methionine by EcMetAP-I, the H178A EcMetAP-I enzyme has been characterized by kinetic and spectroscopic methods in greater detail and its role in the catalytic mechanism is discussed.

\section{Materials and Methods}

Mutagenesis, Protein Expression, and Purification. The H178A altered EcMetAP-I enzyme was generated as previously reported $(\underline{15})$. The codon encoding the H178A mutation was placed in the wild-type (WT) expression system for $E c$ MetAP-I containing the R175Q mutation (mutation eliminating a secondary thrombin cleavage site) in an analogous manner using the following mutagenic primers: $5^{\prime}$-CGG TTG TTC AGC GAA GCC CTG GCC G-3’ and 5'-TGA AGA ACC GCA GGT GCT GCA C-3’. Recombinant WT and H178A EcMetAP-I were expressed and purified as previously described $(\underline{22,23})$. Purified H178A EcMetAPI exhibited a single band on SDS-PAGE and a single symmetrical peak in matrix-assisted laser desorption ionization-time-of-flight (MALDI-TOF) spectrometric analysis indicating $M_{\mathrm{r}}=29630 \pm 10$. Protein concentrations were estimated from the absorbance at $280 \mathrm{~nm}$ using an extinction coefficient of $16450 \mathrm{M}^{-}$ ${ }^{1} \mathrm{~cm}^{-1}$. Apo- $E c$ MetAP-I H178A samples were exchanged into $25 \mathrm{mM}$ HEPES, pH 7.5, containing $150 \mathrm{mM} \mathrm{KCl}$ (Centricon-10, Millipore Corp).

Metal Content Measurements. The H178A EcMetAP-I and wild-type control samples used for metal analysis were typically $30 \mu \mathrm{M}$. Apo- $E c$ MetAP-I samples were incubated under anaerobic conditions with $\mathrm{MCl}_{2}$, where $\mathrm{M}=\mathrm{Co}$ (II) or Fe(II) ( $\mathrm{MCl}_{2}: \geq 99.999 \%$ Strem Chemicals, Newburyport, MA or Aldrich) for 30 min. prior to exhaustive dialysis under anaerobic conditions against Chelex-treated buffer as previously reported $(\underline{22,23})$. Analyses were performed using inductively coupled plasma-atomic emission spectrometry (ICP-AES).

Enzymatic Assay of H178A EcMetAP-I. H178A EcMetAP-I was assayed for catalytic activity with the tetrapeptide MGMM as the substrate $(8 \mathrm{mM})$ using an HPLC method as previously described ( $\underline{23})$. This method is based on the spectrophotometric quantitation of the reaction product GMM following separation on a C8 HPLC column (Phenomenex, Luna; $5 \mu, 4.6 \times 25 \mathrm{~cm}$ ). The kinetic parameter $v$ (velocity) was determined at $\mathrm{pH} 7.5$ by quantifying the tripeptide GMM at $215 \mathrm{~nm}$ in triplicate. One unit of activity is defined as the amount of enzyme that produces one micromole of GMM in one minute. The hydrolysis of MP- $p$-NA was monitored spectrophotometrically at $405 \mathrm{~nm}$ based on the increase in absorbance of $p$-NA $\left(\Delta \varepsilon_{405}\right.$ value of $p$-nitroaniline of $\left.10600 \mathrm{M}^{-1} \mathrm{~cm}^{-1}\right)$ using a coupled assay ( $\underline{32}$ ). The reaction mixture consisted of a $5 \mu \mathrm{L}$ aliquot of a $10 \mu \mathrm{M}$ enzyme solution, $3 \mu \mathrm{L}$ of a $2.0 \mathrm{mM}$ prolidase in $20 \mathrm{mM}$ Tris containing $30 \%$ glycerol. Various concentrations of substrate were added to the enzyme solution to a final volume of 1000 $\mu \mathrm{L}(25 \mathrm{mM}$ HEPES in chelexed water at pH 7.5 containing $150 \mathrm{mM} \mathrm{KCl})$. Enzyme activities are expressed as units/mg, where one unit is defined as the amount of enzyme that releases one micromole of product at 30 ${ }^{\circ} \mathrm{C}$ in one minute. Catalytic activities were determined with an error of $\pm 10 \%$.

Isothermal Titration Calorimetry. Isothermal titration calorimetry (ITC) measurements were carried out on a MicroCal OMEGA ultrasensitive titration calorimeter. The titrant $\left(\mathrm{CoCl}_{2}\right)$ and apo-EcMetAP-I solutions of WT and H178A were prepared in chelexed 25 mM HEPES buffer at pH 7.5, containing $150 \mathrm{mM} \mathrm{KCl}$. Stock buffer solutions were thoroughly degassed before each titration. The enzyme solution $(70 \mu \mathrm{M})$ was placed in the calorimeter cell and stirred at $200 \mathrm{rpm}$ to ensure rapid mixing. Typically, $3 \mu \mathrm{L}$ of titrant was delivered over $7.6 \mathrm{~s}$ with a 5-min interval between injections to allow for complete equilibration. Each titration was continued until 4.5-6 equiv of $\mathrm{Co}$ (II) had been added to ensure that no additional complexes were formed in excess titrant. A background titration, consisting of the identical titrant solution but only 
the buffer solution in the sample cell, was subtracted from each experimental titration to account for heat of dilution. The data were analyzed with a two- or three-site binding model by the Windows-based Origin software package supplied by MicroCal.

pH Studies. The enzymatic activity of WT and H178A EcMetAP-I enzymes were measured using MGMM as the substrate. Apo-enzyme samples were incubated with $\mathrm{Co}(\mathrm{II})$ at $30^{\circ} \mathrm{C}$ for $30 \mathrm{~min}$ prior to reaction to ensure metal binding. The enzyme concentration used in the reaction mixture was $2 \mu \mathrm{M}$ for WT and $6 \mu \mathrm{M}$ for H178A EcMetAP-I. The reaction time was $1 \mathrm{~min}$ for the WT enzyme and $1 \mathrm{~h}$ for H178A EcMetAP-I. All buffers were $30 \mathrm{mM}$ with $150 \mathrm{mM} \mathrm{KCl}$. The buffers used were as follows: pH 5.5-6.0, MES; pH 6.5-6.75, PIPES; pH 7.0-8.0 HEPES; pH 8.0-8.5 EPPS. The kinetic parameters $k_{\text {cat }}, K_{\mathrm{m}}$, and $k_{\text {cat }} / K_{\mathrm{m}}$, were determined using 10-12 different substrate concentrations $(0-16 \mathrm{mM})$ at each $\mathrm{pH}$ value and these data were fit to the Michaelis-Menten equation by nonlinear least-squares methods using IGOR Pro. The enzyme stability at each $\mathrm{pH}$ studied was examined by incubating the enzyme at the desired $\mathrm{pH}$ for the assay time (time of incubation with metal plus reaction) followed by adjustment of the $\mathrm{pH}$ back to $\mathrm{pH} 7.5$ by a 100 -fold dilution with HEPES buffer ( $\mathrm{pH} 7.5,150 \mathrm{mM} \mathrm{KCl}$ ) after which the $\mathrm{pH}$ was reexamined and the specific activity determined.

Spectroscopic Measurements. Electronic absorption spectra were recorded on a Shimadzu UV-3101PC spectrophotometer. All apo- $E c$ MetAP-I samples used in spectroscopic measurements were rigorously anaerobic prior to incubation with $\mathrm{Co}$ (II) $\left(\mathrm{CoCl}_{2}\right)$ for $\sim 20 \mathrm{~min}$ at $25^{\circ} \mathrm{C}$. Co(II)-containing samples were handled throughout in an anaerobic glovebox $\left(\mathrm{N}_{2} / 5 \% \mathrm{H}_{2}, \leq 1 \mathrm{ppm}_{2}\right.$; Coy Laboratories). Electronic absorption spectra were normalized for protein concentration and the absorption due to uncomplexed $\operatorname{Co}(\mathrm{II})\left(\varepsilon_{512 \mathrm{~nm}}=6.0 \mathrm{M}^{-1} \mathrm{~cm}^{-1}\right)$. UV-Vis spectra recorded at different $\mathrm{pH}$ values contained enzyme that had been exchanged into the appropriate buffer at the desired $\mathrm{pH}$ and incubated with one equivalent of $\mathrm{Co}$ (II) at $4{ }^{\circ} \mathrm{C}$.

\section{Results}

Metal Content and Specific Activity of H178A EcMetAP-I. The number of tightly bound divalent metal ions was determined for H178A EcMetAP-I by ICP-AES analysis. Apo-enzyme samples $(30 \mu \mathrm{M})$, to which $2-30$ equiv of $\mathrm{Co}$ (II) or Fe(II) were added under anaerobic conditions, were dialyzed extensively at $4{ }^{\circ} \mathrm{C}$ with chelexed, metal-free HEPES buffer (25 mM HEPES, $150 \mathrm{mM} \mathrm{KCl}, \mathrm{pH} 7.5)$. ICP-AES analysis revealed $1.0 \pm$ 0.1 equiv of cobalt or iron associated with the H178A EcMetAP-I enzyme. These data suggest that only one divalent metal ion is tightly bound to the H178A mutant enzyme, while the second metal ion is labile on the time scale of the buffer exchange $\left(3 \mathrm{~h}, 4^{\circ} \mathrm{C}\right)$.

The specific activity of the H178A EcMetAP-I was examined with MGMM and MP- $p$-NA as substrates. Kinetic parameters were determined for both $\mathrm{Co}$ (II) and Fe(II) reconstituted WT and H178A enzymes (Table 1). The effect on activity after mutating H178 to alanine is in general due to a decrease in $k_{\text {cat. }}$. The $k_{\text {cat }}$ value for Co(II)-loaded H178A decreased 70-fold toward MGMM and 290-fold toward MP- $p$-NA compared to the WT enzyme, while $k_{\text {cat }}$ decreased 50 -fold toward MGMM for the Fe(II)-loaded H178A enzyme and 140-fold toward MP- $p$-NA. The $K_{\mathrm{m}}$ values for MGMM remained unaffected, while those for MP$p$-NA increased approximately 2 -fold for Co(II)- and Fe(II)-loaded H178A (Table 1$)$. The $k_{\text {cat }} / K_{\mathrm{m}}$ values for Co(II)-loaded H178A toward MGMM and MP-p-NA decreased 50 and 580-fold, respectively.

Similarly, $k_{\text {cat }} / K_{\mathrm{m} v a l u e s}$ for Fe(II)-loaded H178A toward MGMM and MP- $p$-NA decreased 50- and 200-fold, respectively.

Table 1: Kinetic Parameters for Hydrolysis of MGMM and MP $p$ NA by Co(II) and Fe(II) Loaded EcMetAP-Ia

\begin{tabular}{|l|l|l|l|l|l|}
\hline & & MGMM & & MP- $p$-NA & \\
\hline & substrate & wild-type & H178A & wild-type & H178A \\
\hline Co(II) & $K_{\mathrm{m}}(\mathrm{mM})$ & $3.2 \pm 0.1$ & $3.2 \pm 0.2$ & $0.06 \pm 0.01$ & $0.12 \pm 0.02$ \\
\hline & $V_{\max }(\mathrm{U} / \mathrm{mg})$ & $77 \pm 3$ & $1.1 \pm 0.1$ & $1.2 \pm 0.2$ & $0.004 \pm 0.002$ \\
\hline & $k_{\text {cat }}\left(\mathrm{s}^{-1}\right)$ & 39 & 0.54 & 0.59 & 0.002 \\
\hline
\end{tabular}




\begin{tabular}{|l|l|l|l|l|l|}
\hline & $k_{\text {cat }} / K_{\mathrm{m}}\left(\mathrm{M}^{-1} \mathrm{~s}^{-1}\right)$ & 12200 & 170 & 9800 & 15 \\
\hline Fe(II) & $K_{\mathrm{m}}(\mathrm{mM})$ & $2.0 \pm 0.3$ & $2.0 \pm 0.3$ & $0.09 \pm 0.01$ & $0.13 \pm 0.02$ \\
& $V_{\max }(\mathrm{U} / \mathrm{mg})$ & $55 \pm 3$ & $1.2 \pm 0.1$ & $2.9 \pm 0.3$ & $0.02 \pm 0.005$ \\
\hline & $k_{\text {cat }}\left(\mathrm{s}^{-1}\right)$ & 28 & 0.56 & 1.4 & 0.01 \\
\hline & $k_{\text {cat }} / K_{\mathrm{m}}\left(\mathrm{M}^{-1} \mathrm{~s}^{-1}\right)$ & 14000 & 280 & 16800 & 85 \\
\hline
\end{tabular}

a Activity assays were performed in $25 \mathrm{mM}$ HEPES, pH 7.5, $150 \mathrm{mM} \mathrm{KCl}$ with $12 \mu \mathrm{M} \mathrm{CoCl}_{2}$ or $\mathrm{Fe}\left(\mathrm{SO}_{4}\right)$.

$\mathrm{Fe}$ (II) Metal Binding Constant for H178A EcMetAP-I. The extent of hydrolytic activity exhibited by the H178A EcMetAP-I enzyme was determined as a function of Fe(II) concentration (Figure 1). The H178A apo- $E c$ MetAP-I enzyme was incubated for 30 min under anaerobic conditions at $\mathrm{pH} 7.5$ with varying amounts of $\mathrm{Fe}(\mathrm{II})$ and the level of catalytic activity was determined. Upon the addition of Fe(II) to H178A EcMetAP-I, the specific activity increased as a function of metal ion concentration and exhibited a maximum activity of $\sim 1.1$ units $\mathrm{mg}^{-1}$ after the addition of only one equivalent of $\mathrm{Fe}(\mathrm{II})$. Further additions resulted in little change in the observed level of activity and above four equivalents of Fe(II), the enzymatic activity decreased. These data are identical to those observed for Fe(II) binding to WT EcMetAP-I $(\underline{22}, 23)$. The activity titration data for Fe(II) binding to the H178A EcMetAP were fit to eq 1 (Figure 1) ( $\underline{33}$ ):

$$
r=p C_{s} /\left(K_{d}+C_{s}\right)
$$

where $p$ is the number of sites for which interaction with ligand is governed by the intrinsic dissociation constant $K_{\mathrm{d}}, C_{\mathrm{s}}$ is the free metal concentration ( $\mathrm{Fe}_{\text {free }}$ in this case), and $r$ is the binding function which was calculated by conversion of the fractional saturation $\left(r=f_{\mathrm{a}} p\right)$ as previously described $(\underline{23})$. Free metal concentration was calculated from

$$
C_{S}=C_{T S}+r C_{A}(2)
$$

where $C_{\mathrm{TS}}$ and $C_{\mathrm{A}}$ are the total molar concentrations of metal and enzyme, respectively. The best fit obtained exhibited a $p$ value of 1 and a $K_{\mathrm{d}}$ value of $0.30 \pm 0.15 \mu \mathrm{M}$ (Figure 1). These data are identical, within error, to those obtained for Fe(II) binding to WT EcMetAP-I $\left(K_{\mathrm{d}}=0.20 \pm 0.15 \mu \mathrm{M}\right)(\underline{23})$.

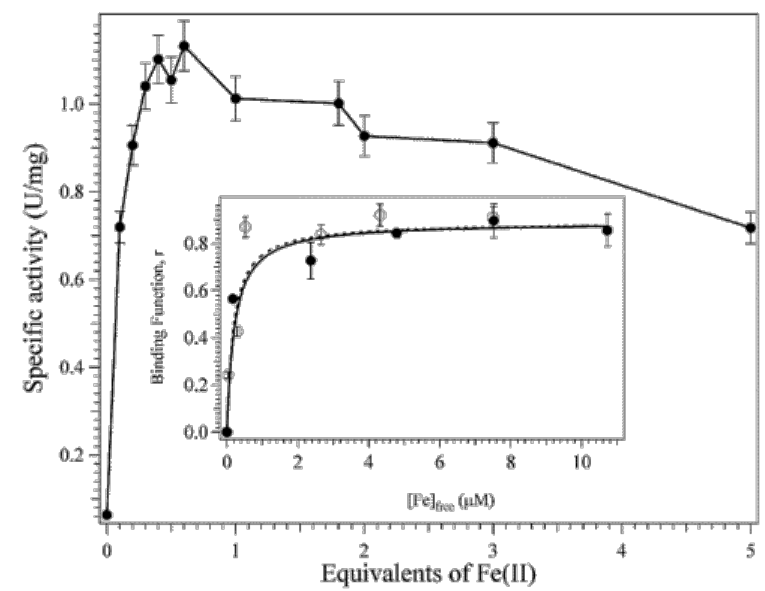

Figure 1 Plot of specific activity (U/mg) of H178A EcMetAP-I vs equivalents of Fe(II). Activity assays were performed with $8 \mathrm{mM}$ MGMM in $25 \mathrm{mM}$ HEPES, pH 7.5, $150 \mathrm{mM} \mathrm{KCl}$. Inset: Plot of binding function, $r$, vs free $\mathrm{Fe}(\mathrm{II})$ concentration, $\mathrm{Fe}(\mathrm{II})_{\text {free, }}$ for WT EcMetAP-I (O) and H178A EcMetAP-I ( $)$. The solid line represents a fit of Fe(II) activity titration data for H178A EcMetAP-I to eq 1. This fit provided a value of $p=$ 1 and a $K_{\mathrm{d}}$ value of $0.30 \pm 0.15 \mu \mathrm{M}$ (Figure 1). These data are identical, within error, to those obtained for Fe(II) binding to WT EcMetAP-I (dashed line, $K_{\mathrm{d}}=0.20 \pm 0.15 \mu \mathrm{M}$ ).

Isothermal Titration Calorimetry. Isothermal titration calorimetry (ITC) measurements were carried out at $20 \pm 0.2^{\circ} \mathrm{C}$ for both WT and H178A EcMetAP-I (Figure 2A,C). Association constants $\left(K_{\mathrm{b}}\right)$ were obtained by 
fitting these data, after subtraction of the background heat of dilution, via an iterative process using the Origin software package. This software package uses a nonlinear least-squares algorithm that allows the concentrations of the titrant and the sample to be fit to the heat-flow-per-injection to an equilibrium binding equation for two sets of noninteracting sites. The $K_{\mathrm{b}}$ value, the metal-enzyme stoichiometry $(n)$, and the change in enthalpy $\left(\Delta H^{\circ}\right)$ were allowed to vary during the fitting process (Table 2, Figure $2 \mathrm{~B}, \mathrm{D}$ ). The best fits obtained for both WT and altered $E c$ MetAP-I provided an overall $n$ value of 3 for three noninteracting sites. Attempts to fit these data with $n$ values of 1 or 2 provided poor fits, as did fits in which the $n$ value was 3 but the binding process was considered cooperative. For WT EcMetAP-I, a $K_{\mathrm{d}}$ value of 6.4 $\pm 0.5 \mu \mathrm{M}$ was observed as well as two $K_{\mathrm{d}}$ values of $14 \pm 5 \mathrm{mM}$. On the other hand, a $K_{\mathrm{d}}$ value of $12.5 \pm 0.5$ $\mu \mathrm{M}$ and two $K_{\mathrm{d}}$ values of $29 \pm 5 \mathrm{mM}$ were obtained for H178A. These data correspond to individual binding events of three $\mathrm{Co}(\mathrm{II})$ ions to the EcMetAP-I WT and H178A altered enzyme.
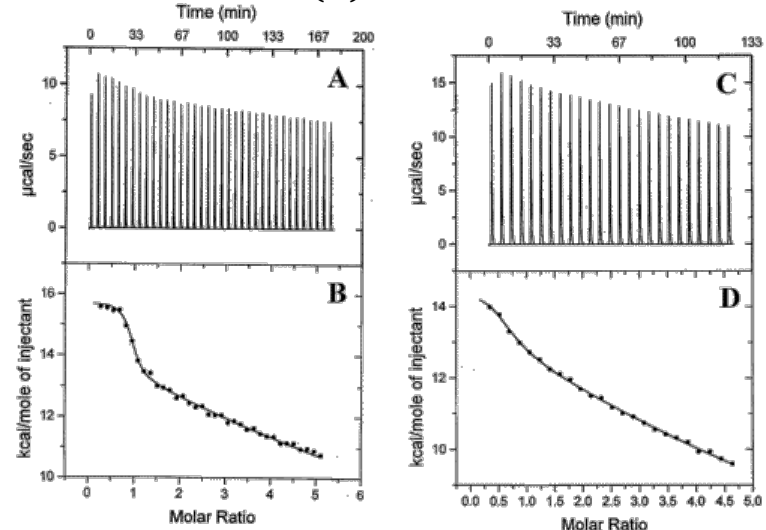

Figure 2 (A) ITC titration of a $70 \mu \mathrm{M}$ solution of WT EcMetAP-I with a $5 \mathrm{mM}$ Co(II) solution. (C) ITC titration of a $70 \mu \mathrm{M}$ solution of H178A EcMetAP-I with a $5 \mathrm{mM}$ Co(II) solution. (B) Fit of the ITC data for WT EcMetAP-I and (D) for H178A EcMetAP-I after subtraction of the heat of dilution. The fits were obtained using noninteracting sites model and provided an overall $n$ value of 3 , with one tight and two loose sites. Reaction conditions: $20^{\circ} \mathrm{C}$ in $25 \mathrm{mM}$ HEPES, pH 7.5, and $150 \mathrm{mM} \mathrm{KCl}$.

Table 2: Dissociation Constants $\left(K_{\mathrm{d}}\right)$ and Metal-Enzyme Stoichiometry $(n)$ for Co(II) Binding to Wild-Type and H178AEcMetAP-Ia

\begin{tabular}{|l|l|l|}
\hline$E c M e t A P-1$ & $n$ & $K_{\mathrm{d}} 1, K_{\mathrm{d}} 2(\mu \mathrm{M})$ \\
\hline & 1 & $6.4 \pm 0.5$ \\
\hline wild-type & 2 & $14000 \pm 5000$ \\
\hline & 1 & $12.5 \pm 0.5$ \\
\hline H178A & 2 & $29000 \pm 5000$ \\
\hline
\end{tabular}

${ }^{a}$ For each set of data for both WT and H178A EcMetAP-I, $n$ is the number of Co(II) ions per protein. Data for $n=1$ are for one Co(II) ion that bound tightly, and data for $n=2$ represent two Co(II) ions binding to sites on protein with lower affinity.

pH Dependence of Kinetic Parameters of WT and H178A EcMetAP-I. The $\mathrm{pH}$ dependence of $K_{\mathrm{m}}$ and $V_{\max }$ for WT and H178A EcMetAP-I was examined using MGMM as the substrate (Figure 3). Both WT and H178A EcMetAP-I displayed optimum catalytic efficiency and maximal activity between $\mathrm{pH} 7.2$ and 7.8. The stability of both enzymes at each $\mathrm{pH}$ value studied was also examined by incubating the enzyme at the desired $\mathrm{pH}$ for the assay time (30 min for WT vs $90 \mathrm{~min}$ for H178A EcMetAP-I) followed by adjustment of the $\mathrm{pH}$ back to 7.5 after which the specific activity was determined at $8 \mathrm{mM}$ MGMM. For WT EcMetAP-I, full enzymatic activity was recovered up to $\mathrm{pH} 8.25$ above which the recoverable activity decreased by $15 \%$ or greater. On the other hand, the amount of recoverable activity for the H178A altered EcMetAP-I enzyme decreased rapidly at $\mathrm{pH}$ values greater than $\sim 7.8$, indicating a loss of stability under these conditions. For both $\log \left(k_{\text {cat }}\right)$ and $\log \left(k_{\text {cat }} / K_{\mathrm{m}}\right)$, the data obtained above $\mathrm{pH} 8.0$ were corrected for the $\%$ loss in activity by eq 3 
by normalizing for the activity recoveredafter returning to a standard $\mathrm{pH}$ (Figure 3B). This could be done only for the wild-type enzyme because of the short reaction time as compared to total assay time during which the enzyme was exposed to high $\mathrm{pH}$.
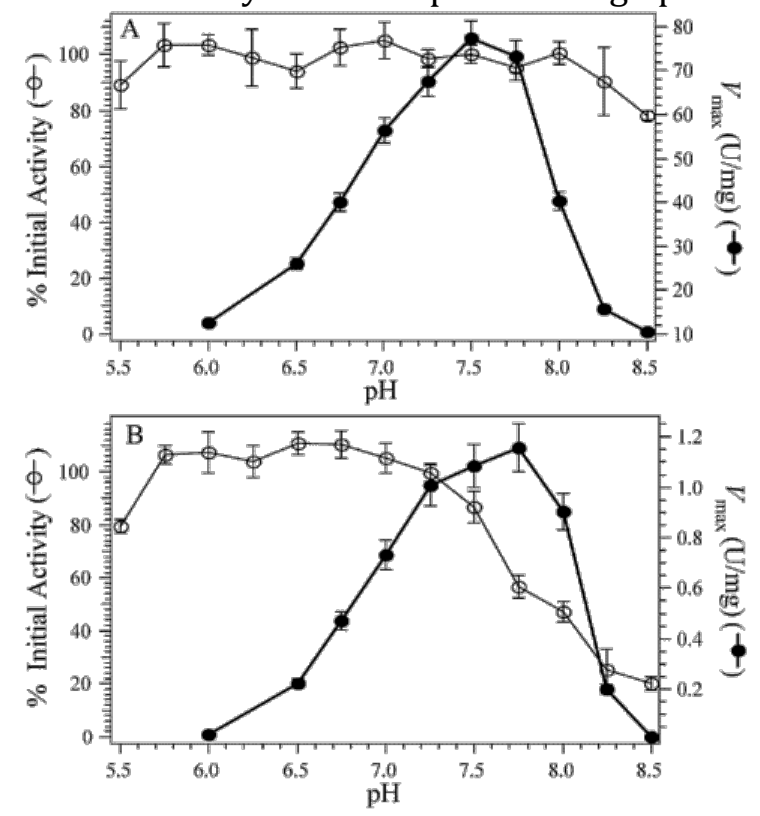

Figure 3 (A) Plot of $V_{\max }$ vs pH for WT EcMetAP-I ( $\left.\cdot\right)$ and a percent of activity recovered after incubating the enzyme at the desired $\mathrm{pH}$ for the assay time (30 min + one minute) followed by adjustment of the $\mathrm{pH}$ back to 7.5 after which the specific activity was determined (O). (B) Plot of $V_{\max }$ Vs pH for H178A EcMetAP-I (·) and a percent of activity recovered after incubating the enzyme at the desired $\mathrm{pH}$ for the assay time (30 min $+1 \mathrm{~h}$ ) followed by adjustment of the $\mathrm{pH}$ back to 7.5 after which the specific activity was determined (O). The assays were performed using $8 \mathrm{mM}$ MGMM as substrate. The Co(II) concentration in the assay was $12 \mu \mathrm{M}$.

Plots of $\log \left(k_{\text {cat }}\right)$ and $\log \left(k_{\text {cat }} / K_{\mathrm{m}}\right)$ vs pH were prepared for both WT and H178A EcMetAP-I and fit to eqs 4 and 5 , respectively (Figures 4 and 5$)(\underline{34,35})$ :

$$
\begin{gathered}
\log \left(k_{\text {cat }}\right)=\log \left[k_{\text {cat }}^{\prime} /\left(1+[\mathrm{H}] / K_{\mathrm{ES} 1}+K_{\mathrm{ES} 2} /[\mathrm{H}]\right)\right](4) \\
\log \left(/ K_{\mathrm{m}}\right)=\log \left[\left(k_{\text {cat }}^{\prime} / K_{\mathrm{m}}^{\prime}\right) /\left(1+[\mathrm{H}] / K_{\mathrm{E} 1}+K_{\mathrm{E} 2} /[\mathrm{H}]\right)\right](5)
\end{gathered}
$$

Where $k_{\text {cat }}$ is the theoretical maximal velocity, $k_{\text {cat }} / K_{\mathrm{m}}^{\prime}$ is the theoretical maximal catalytic efficiency, $K_{\mathrm{ES}}$ is the ionization constant of the ES complex which affects the acidic side of the $\mathrm{pH}$ curve, $K_{\mathrm{ES} 2}$ reflects the basic side, and $K_{\mathrm{E} 1}$ and $K_{\mathrm{E} 2}$ are ionization constants for an acidic and basic group, respectively, on the free enzyme or free substrate (Scheme 1). For the $\mathrm{pH}$ dependence of log $K_{\mathrm{m}}$ of WT EcMetAP-I a graphical method was used to determine the p $K$ values ( $\underline{36}$ ). There are at least two ionizations present with $\mathrm{p} K^{\prime} \mathrm{s}$ of 7.5 and 7.9 , and the slope of the asymptote is 1 (Figure 4A, Table 3). 


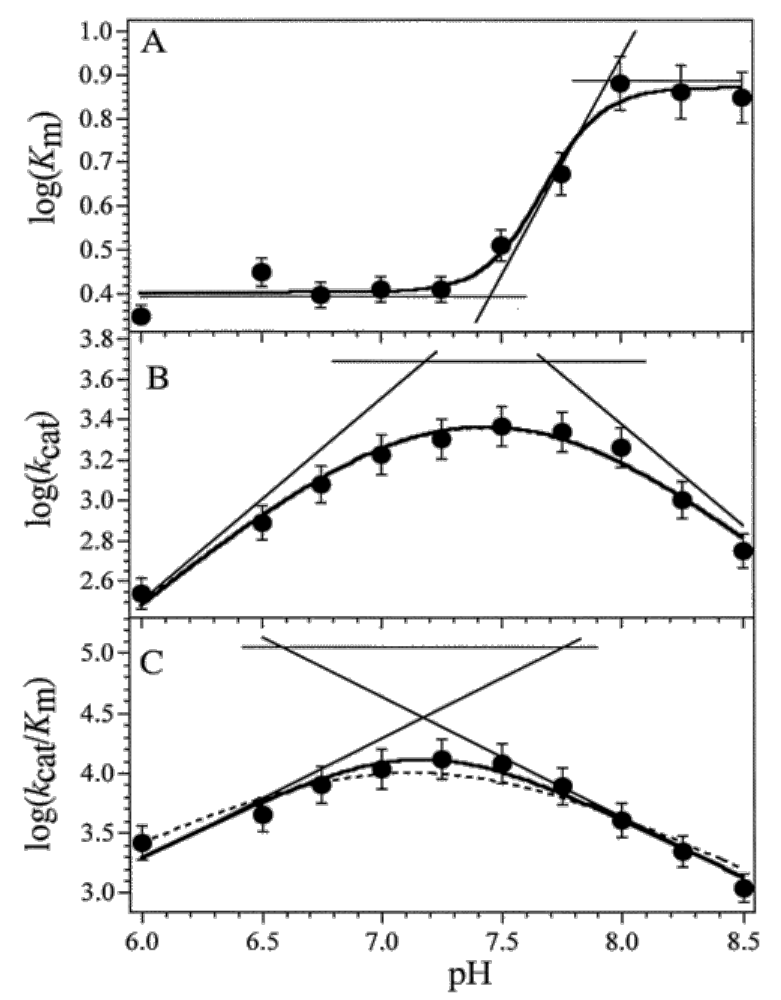

Figure $4 \mathrm{pH}$ dependence of the kinetic parameters for the hydrolysis of MGMM by WT $E c$ MetAP-I between pH 6.0 and 8.5. Data were fitted to eqs 4 and 5 (solid line) plots B and C, respectively. The same data were also fit to eq 10 and 11 (dashed line). (A) $\log \left(K_{\mathrm{m}}\right)$ vs. $\mathrm{pH}$. The values $\mathrm{p} K_{\mathrm{a}}=7.5 \pm 0.1$ and $7.9 \pm 0.1$ were obtained using graphical method. The solid line represents a fit to equation describing a sigmoidal curve and was not used for calculations. (B) $\log \left(k_{\mathrm{cat}}\right) \mathrm{vs} \mathrm{pH}\left\{\mathrm{p} K_{\mathrm{ES} 1}=7.2 \pm 0.1\right.$ and $\mathrm{p} K_{\mathrm{ES} 2}=7.7 \pm 0.1, k_{\text {cat }}^{\prime}=(5 \pm 1)$ $\left.\times 10^{3}\right\}$. (C) $\log \left(k_{\text {cat }} / K_{\mathrm{m}}\right)$ vs $\mathrm{pH}\left\{\mathrm{p} K_{\mathrm{E} 1}=7.7 \pm 0.5\right.$ and $\left.\left.\mathrm{p} K_{\mathrm{E} 2}=6.6 \pm 0.5, \tilde{k}_{\mathrm{cat}} / \tilde{K}_{\mathrm{m}}=(1.1 \pm 0.2) \times 10^{5}\right)\right\}$.

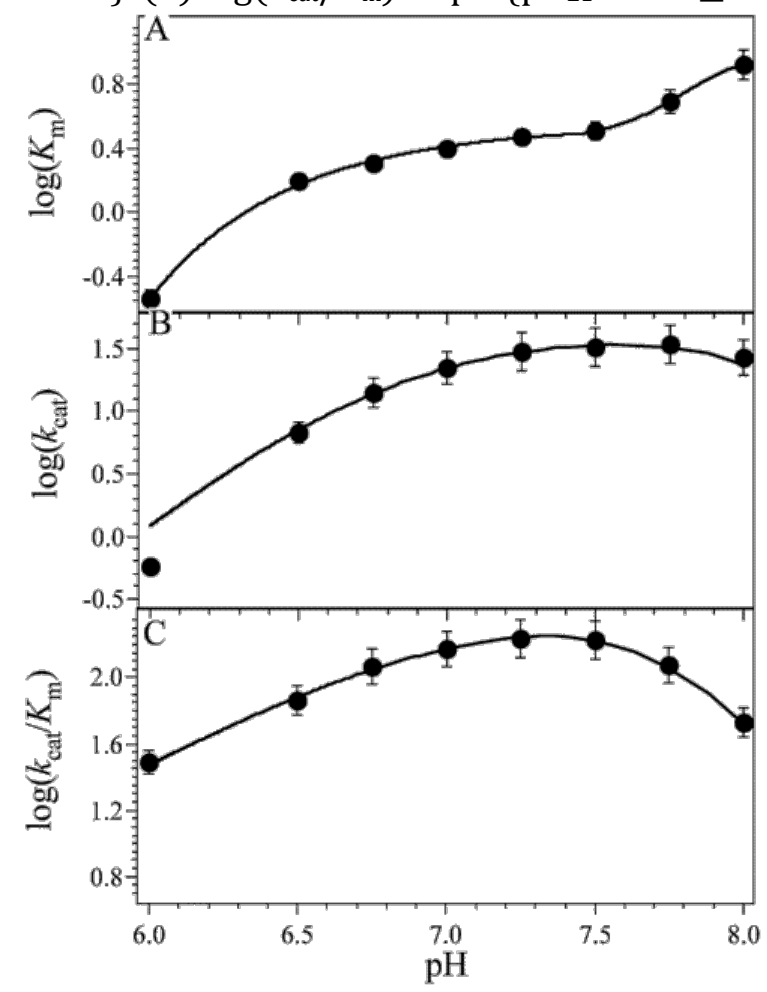

Figure $5 \mathrm{pH}$ dependence of the kinetic parameters for the hydrolysis of MGMM by H178A EcMetAP-I between pH 6.0 and 8.0. (A) $\log \left(K_{\mathrm{m}}\right)$ vs pH. (B) $\log \left(k_{\text {cat }}\right)$ vs pH. (C) $\log \left(k_{\text {cat }} / K_{\mathrm{m}}\right)$ vs pH. 


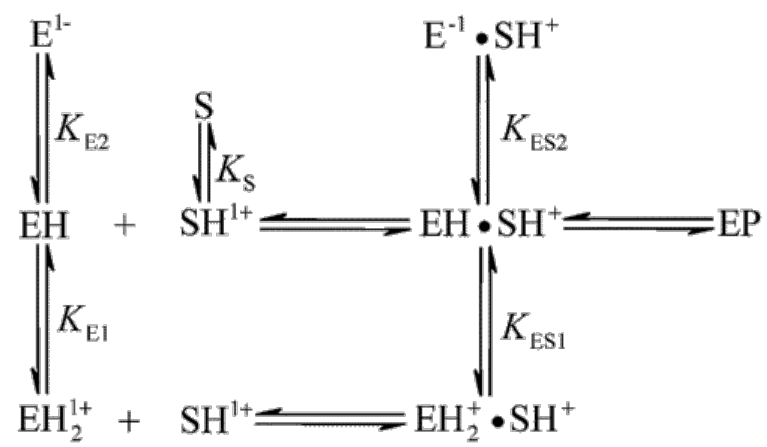

Scheme $1^{a}$

${ }^{a}$ Molecular dissociation constants are represented by $K_{\mathrm{E} 1}$ and $K_{\mathrm{E} 2}$ for the free enzyme, by $K_{\mathrm{S}}$ for the free substrate, and $K_{\mathrm{ES} 1}$ and $K_{\mathrm{ES} 2}$ represent those for the enzyme-substrate complex.

Table 3: Ionization Constants for WT EcMetAP-Ia

\begin{tabular}{|c|c|c|c|}
\hline$K_{\mathrm{m}}$ vs pH & & & \\
\hline $\mathrm{p} K_{1}$ & & $7.5 \pm 0.1$ & \\
\hline $\mathrm{p} K_{2}$ & & $7.9 \pm 0.1$ & \\
\hline$k_{\text {cat }}$ vs pH & equation 4 & & equation 10 \\
\hline $\mathrm{p} K_{\mathrm{ES} 1}$ & $7.2 \pm 0.1$ & & $7.4 \pm 0.3$ \\
\hline $\mathrm{p} K_{\mathrm{ES} 2}$ & $7.7 \pm 0.1$ & & $7.4 \pm 0.3$ \\
\hline$k_{\text {cat }}^{\prime}$ & $(5 \pm 1) \times 10^{3}$ & & $(9 \pm 2) \times 10^{3}$ \\
\hline$k_{\text {cat }} / K_{\mathrm{m}} \mathrm{Vs} \mathrm{pH}$ & equation 5 & & equation 11 \\
\hline $\mathrm{p} K_{\mathrm{E} 1}$ & $7.7 \pm 0.5$ & & $7.1 \pm 1$ \\
\hline $\mathrm{p} K_{\mathrm{E} 2}$ & $6.6 \pm 0.6$ & & $7.1 \pm 1$ \\
\hline$k_{\text {cat }}^{\prime} / K_{\mathrm{m}}^{\prime}$ & $(1.1 \pm 0.2) \times 10^{5}$ & & $(4.0 \pm 0.1) \times 10^{5}$ \\
\hline
\end{tabular}

${ }^{a}$ For the pH dependence of $\log \left(K_{\mathrm{m}}\right)$ of WTEcMetAP-I, a graphical method was used to determine the $\mathrm{p} K$ values $(\underline{36})$. Plots of $\log \left(k_{\text {cat }}\right)$ and $\log \left(k_{\text {cat }} / K_{\mathrm{m}}\right)$ vs $\mathrm{pH}$ were fit to eqs 4 and 5 , respectively. Since the obtained $\mathrm{p} K_{\mathrm{a}}$ values differed by less than 0.6 unit the data were also fit to eqs 10 and 11, which are recommended in such cases $(\underline{39})$.

A plot of $\log \left(k_{\text {cat }}\right)$ vs. pH is a bell-shaped curve that was fit to eq 4 (Figure 4B). A good fit was obtained, which yielded $\mathrm{p} K_{\mathrm{ES} 1}$ of $7.2 \pm 0.1$ and $\mathrm{p} K_{\mathrm{ES} 2}$ of $7.7 \pm 0.1$ and $k_{\text {cat }}^{\prime}=(5 \pm 1.0) \times 10^{3} \mathrm{~min}^{-1}$ (Table 3$)$. In addition, fits of $\log \left(k_{\mathrm{cat}} / K_{\mathrm{m}}\right)$ vs $\mathrm{pH}$ to eq 5 provided $\mathrm{p} K_{\mathrm{E} 1}=7.7 \pm 0.5, \mathrm{p} K_{\mathrm{E} 2}=6.6 \pm 0.6$, and $k_{\text {cat }}^{\prime} / k_{\mathrm{m}}^{\prime}=(1.1 \pm$ $0.2) \times 10^{5} \mathrm{M}^{-1} \mathrm{~s}^{-1}$. Since $\mathrm{p} K_{\mathrm{E} 2}$ is less than $\mathrm{p} K_{\mathrm{E} 1}$, this suggests positive cooperativity for proton binding. The low and high pH asymptotes for plots of log $k_{\mathrm{cat}} \mathrm{Vs} \mathrm{pH}$ were calculated using eqs 6 and 7, while low and high $\mathrm{pH}$ asymptotes for $\log \left(k_{\mathrm{cat}} / K_{\mathrm{m}}\right)$ vs $\mathrm{pH}$ were obtained using eqs 8 and 9 ( $\left.\underline{37}\right)$.

$$
\begin{gathered}
\log (\mathrm{y})=\log \left(k_{\text {cat }}^{\prime}\right)+\mathrm{pH}-\mathrm{p} K_{\mathrm{ES} 1}(6) \\
\log (\mathrm{y})=\log \left(k_{\text {cat }}^{\prime}\right)+\mathrm{pH}-\mathrm{p} K_{\mathrm{ES} 2}(7) \\
\log (\mathrm{y})=\log \left(k_{\text {cat }}^{\prime} / k_{\mathrm{m}}^{\prime}\right)+\mathrm{pH}-\mathrm{p} K_{\mathrm{E} 1}(8) \\
\log (\mathrm{y})=\log \left(k_{\text {cat }}^{\prime} / k_{\mathrm{m}}^{\prime}\right)+\mathrm{pH}-\mathrm{p} K_{\mathrm{E} 2}(9)
\end{gathered}
$$

The asymptotes for $k_{\text {cat }}$ have slopes of 1.0 and -1.0 and cross the $k_{\text {cat }}^{\prime}$ at $\mathrm{p} K_{\mathrm{ES} 1}$ and $\mathrm{p} K_{\mathrm{ES} 2}$ (Figure $4 \mathrm{~B}$ ). The asymptotes for plots of $\log \left(k_{\text {cat }} / K_{\mathrm{m}}\right)$ have slopes of 1.0 and -1.0 and exhibit crossover points at the theoretical maximal catalytic efficiency which gives the $\mathrm{p} K_{\mathrm{E} 1}$ and $\mathrm{p} K_{\mathrm{E} 2}$ values (Figure $4 \mathrm{C}$ ). The two $\mathrm{p} K^{\prime} \mathrm{s}$ are separated by less than $2 \mathrm{pH}$ units and the observed apparent $k_{\text {cat }}$ is below $k_{\text {cat }}^{\prime}$. In this case, the crossover point of the observed apparent $k_{\text {cat }}$ with the asymptotes on the $\mathrm{pH}$ curve do not provide $\mathrm{p} K^{*} \mathrm{~s}(34,37,38)$. 
The determination of $\mathrm{p} K_{\mathrm{ES} 1}$ and $\mathrm{p} K_{\mathrm{ES} 2}$ becomes inaccurate when $\mathrm{p} K_{\mathrm{ES} 2}$ falls below $\mathrm{p} K_{\mathrm{ES} 1}$ (i.e., when there is strongly cooperative proton binding). The reason for this is that the width of the curve at half its maximal height becomes insensitive to changes in the difference between $\mathrm{p} K_{\mathrm{ES} 2}$ and $\mathrm{p} K_{\mathrm{ES} 1}$ and when $\mathrm{p} K_{\mathrm{ES} 1}>$ $\mathrm{p} K_{\mathrm{ES} 2}(\underline{38})$. For such cases, eqs 10 and 11 are required $(\underline{39})$. Fits of $\log \left(k_{\mathrm{cat}}\right)$ vs. pH to eq 10 provided $\mathrm{p} K_{\mathrm{ES} 1}=$ $7.4 \pm 0.3, \mathrm{p} K_{\mathrm{ES} 2}=7.4 \pm 0.3$ and $k_{\text {cat }}^{\prime}=(9 \pm 2) \times 10^{3} \mathrm{~min}^{-1}$. Fits of $\log \left(k_{\text {cat }} / K_{\mathrm{m}}\right) \mathrm{vs}$. pH to eq 11 provided $\mathrm{p} K_{\mathrm{E} 1}=7.1 \pm 1, \mathrm{p} K_{\mathrm{E} 2}=7.1 \pm 1$ and $k_{\text {cat }}^{\prime} / k_{\mathrm{m}}^{\prime}=(4.0 \pm 0.1) \times 10^{5} \mathrm{M}^{-1} \mathrm{~s}^{-1}$.

$$
\begin{aligned}
\log \left(k_{\mathrm{cat}}^{\prime}\right) & =\log \left\{k_{\mathrm{cat}}^{\prime} /\left[\left(1+[\mathrm{H}] / K_{\mathrm{ES} 1}\right)\left(1+K_{\mathrm{ES} 2} /[H]\right)\right]\right\} \\
\log \left(k_{\mathrm{cat}}^{\prime} / K_{\mathrm{m}}\right) & =\log \left\{\left(k_{\mathrm{cat}}^{\prime} / K_{\mathrm{m}}^{\prime}\right) /\left[\left(1+[\mathrm{H}] / K_{\mathrm{E} 1}\right)\left(1+K_{\mathrm{E} 2} /[\mathrm{H}]\right)\right]\right\}(11)
\end{aligned}
$$

Attempts were made to fit the pH-dependent data for H178A EcMetAP-I to the equations described above but failed to yield reasonable $\mathrm{p} K$ values (Figure 5 ). Yet, some qualitative descriptions of the $\mathrm{pH}$-dependent $\log \left(K_{\mathrm{m}}\right), \log \left(k_{\mathrm{cat}}\right), \log \left(k_{\mathrm{cat}} / K_{\mathrm{m}}\right)$ can be made in comparison to the WT data. Plots of $\log \left(k_{\text {cat }}\right) \operatorname{or} \log \left(k_{\text {cat }} / K_{\mathrm{m}}\right)$ vs pH likely form a bell-shaped curve, but this assertion cannot be made conclusively due to the lack of data points above $\mathrm{pH}$ 8.0. The acidic limbs of the curves for $\log \left(k_{\text {cat }}\right)$ vs $\mathrm{pH}$ (Figure $\left.5 \mathrm{~B}\right)$ and $\log \left(k_{\text {cat }} / K_{\mathrm{m}}\right)$ vs $\mathrm{pH}$ (Figure 5C) have slopes near 1 and increase with increasing $\mathrm{pH}$ up to $\mathrm{pH} 7.8$ and 7.3, respectively. $\mathrm{p} K$ values are not presented due to the lack of data above $\mathrm{pH} 7.8$.

pH Dependence of the Electronic Absorption Spectra of the Co(II)-Substituted WT and H178A EcMetAP-I Enzymes. Electronic absorption spectra of the Co(II)-substituted forms of the WT and H178A EcMetAP-I enzymes were recorded at several $\mathrm{pH}$ values between 6.0 and 9.0. At a pH value of 7.5, the electronic absorption spectrum of WT EcMetAP-I with one equivalence of Co(II) contains three absorption maxima at $570 \mathrm{~nm}\left(\varepsilon=130 \mathrm{M}^{-1} \mathrm{~cm}^{-1}\right), 640 \mathrm{~nm}\left(\varepsilon=135 \mathrm{M}^{-1} \mathrm{~cm}^{-1}\right)$, and $690 \mathrm{~nm}\left(\varepsilon=105 \mathrm{M}^{-1} \mathrm{~cm}^{-1}\right)$ that can be attributed to $\mathrm{Co}$ (II) $\mathrm{d}-\mathrm{d}$ transitions (Figure 6). The coordination number of the active site $\mathrm{Co}$ (II) ion in EcMetAP-I at pH 7.5 is five. However, increasing the pH to 9.0 increases the molar absorptivity at $\lambda_{\max } 640 \mathrm{~nm}$ from 135 to $290 \mathrm{M}^{-1} \mathrm{~cm}^{-1}$ while decreasing the $\mathrm{pH}$ from 7.5 to 6.5 decreases the molar absorptivity from 135 to $50 \mathrm{M}^{-1} \mathrm{~cm}^{-1}$ (Figure 6). Interestingly, a similar trend is observed for H178A EcMetAP-I, except that the spectra with similar molar absorptivities to the WT enzyme occur at pH values $0.5 \mathrm{pH}$ units more acidic. A plot of molar absorptivity $(\varepsilon)$ of the $\lambda_{\max }$ value at $640 \mathrm{~nm}$ vs pH provides simple sigmoidal curves for both WT and H178A EcMetAP-I (Figure 7). These data were fit to eq 12

$$
\varepsilon=\varepsilon_{\min }+\varepsilon_{\max } /\left[1+\exp \left\{\left(\mathrm{p} K_{\mathrm{a}}-\mathrm{pH}\right) / \mathrm{slope}\right\}\right](12)
$$

which gave apparent $\mathrm{p} K_{\mathrm{a}}$ values of $8.1 \pm 0.5$ and $7.6 \pm 0.3$ for WT and H178A $E c$ MetAP-I, respectively.

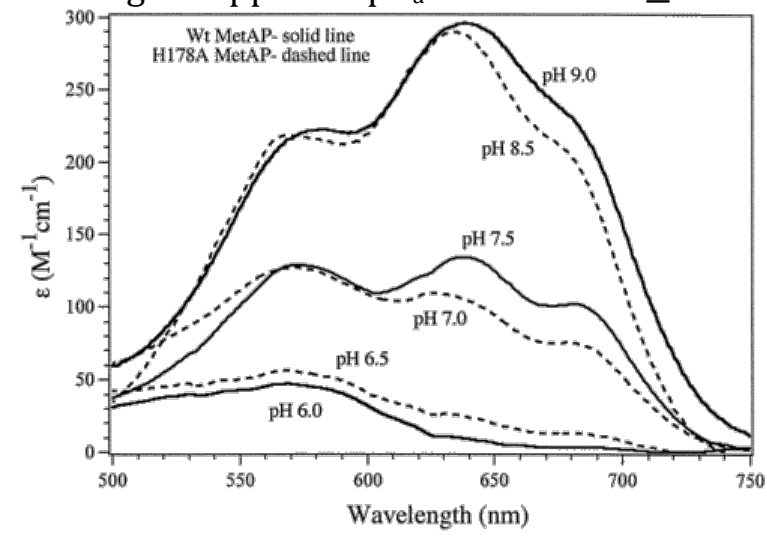

Figure 6 Electronic absorption spectra of Co(II)-loaded WT (solid line) and H178A (dashed line) EcMetAPI. Visible spectra were recorded at various $\mathrm{pH}$ for $1 \mathrm{mM}$ WT and H178A EcMetAP with one equivalence of Co(II). 


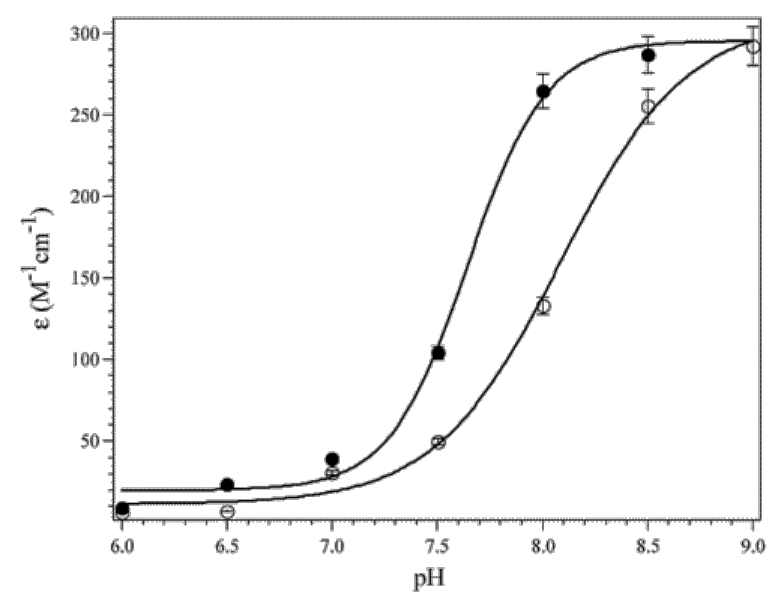

Figure 7 Plots of extinction coefficient $(\varepsilon)$ at $640 \mathrm{~nm}$ vs pH for wild type (O) and H178A (·) EcMetAP-I. The solid lines represent a fit to an equation of a sigmoidal curve. The midpoints of each curve provided $\mathrm{p} K_{\mathrm{a}}$ values 8.0 and 7.6 for WT and H178A EcMetAP-I, respectively.

\section{Discussion}

Histidine-178 is strictly conserved in all MetAPs sequenced to date, and it has been suggested that the imidazole of $\mathrm{H} 178$ plays a role in the catalytic removal of $\mathrm{N}$-terminal methionine residues from polypeptide chains by MetAPs $(20,21,31)$. Previously, it was shown that the H178A EcMetAP-I altered enzyme exhibited 50-fold lower activity toward norleucine-Ala-Ala-Glu-Glu (Nle-AAEE) in comparison to WT enzyme $(\underline{20})$. On the basis of these data, it was suggested that H178, while important for catalysis, was not a catalytically required residue. To more clearly define the role of $\mathrm{H} 178$ in catalysis, we have examined the H178A altered EcMetAP-I enzyme and found that the amount of catalytic activity retained $(\sim 1.5 \%)$ is dependent on both the substrate and the divalent metal ion present.

The specific activity of H178A altered EcMetAP-I enzyme was determined in the presence of both the tetrapeptide MGMM and the para-nitroanilide substrate MP- $p$-NA. Kinetic parameters for both Co(II)- and Fe(II)-loaded WT and H178A enzymes indicate that, in general, the effect on activity is due to a decrease in $k_{\text {cat }}$ (Table 1). $K_{\mathrm{m}}$ values were not affected for MGMM but increased moderately ( 2 -fold) for MP- $p$-NA. It is possible that $\mathrm{H} 178 \mathrm{~A}$ forms an hydrogen bond with either the $\mathrm{NO}_{2}$ or the proline group of MP- $p$-NA, but at this time nothing is known about how this substrate interacts with MetAPs. The combination of these data, indicate that while $\mathrm{H} 178$ plays a role in the catalytic mechanism, it is not a critical residue since a significant amount of catalytic activity is retained even in its absence.

H178A EcMetAP-I was found to bind only one divalent metal ion tightly, which is identical to the WT enzyme. Therefore, alteration of $\mathrm{H} 178$ does not affect the ability of the enzyme to bind divalent metal ions. These data are also consistent with the $K_{\mathrm{d}}$ values determined by both kinetic and ITC measurements. The $K_{\mathrm{d}}$ values determined for Fe(II) binding to WT and H178A EcMetAP-I by activity titrations (0.2 vs 0.3 $\mu \mathrm{M}$, respectively) are identical within error. On the other hand, the $K_{\mathrm{d}}$ values obtained for Co(II) binding to WT and H178A measured by ITC are similar but slightly different (6.5 vs $12.5 \mu \mathrm{M}$, respectively) from each other (Table 2). The small difference in Co(II) $K_{\mathrm{d}}$ values between WT and the H178A enzyme likely reflects the lack of hydrogen bond formation in the H178A enzyme. As shown in the X-ray structure of EcMetAP-I, H178 forms a hydrogen bond to a water molecule, which in turn forms a hydrogen bond to the water molecule that binds to the catalytic divalent metal ion. The loss of this hydrogen bonding interaction may slightly perturb the enzymes ability to coordinate the active site divalent metal ion.

The catalytic role of $\mathrm{H} 178$ was further examined by recording the $\mathrm{pH}$ dependence of $V_{\max }$ for Co(II)-loaded WT and H178AEcMetAP-I. Plots of $V_{\max }$ vs pH are bell shaped for both WT and H178A Co(II)loaded EcMetAP-I (Figure 3). In addition, both enzymes displayed optimum catalytic efficiency and maximal activity between $\mathrm{pH}$ values of 7.5 and 7.8 toward MGMM. However, enzyme stability studies 
indicated that the H178A enzyme quickly loses activity above $\mathrm{pH} 7.5$, and little if any activity could be recovered after the enzyme was incubated at $\mathrm{pH} 8.5$ for the time required to perform the assay $(>1 \mathrm{~h})$ (Figure 3B). Therefore, no useful $\mathrm{p} K_{\mathrm{a}}$ data could be obtained from log plots of kinetic constants vs $\mathrm{pH}$ at $\mathrm{pH}$ values above 7.8 for the H178A EcMetAP-I enzyme.

Inspection of the plot of $\log \left(K_{\mathrm{m}}\right)$ vs $\mathrm{pH}$ for WT $E c$ MetAP-I shows two inflections at ca. 7.5 and 7.9 where the asymptote of the sigmoidal region meets the flat, $\mathrm{pH}$-independent regions. The inflection at $\mathrm{pH} 7.5$ indicates that a protonated form of the substrate or a group on the enzyme results in increased substrate binding affinity assisting in ES complex formation. This $\mathrm{p} K_{\mathrm{a}}$ value is assigned to the deprotonation of the $\mathrm{N}$-terminal $\alpha$-amino group of the substrate MGMM ( $\left.\mathrm{p} K_{\mathrm{S}}\right)$. This assignment is based on the $\mathrm{p} K_{\mathrm{a}}$ of N-terminal amine of MGMM which is $7.5(\underline{40})$ and also upon the similarity of the observed $\mathrm{p} K_{\mathrm{a}}$ to the $\mathrm{p} K_{\mathrm{a}}$ of the N-terminal $\alpha$ amino group of the substrate L- $p$-NA which is $7.74(\underline{41})$. These data indicate that the protonated form of the substrate binds to the enzyme more tightly than the deprotonated form. At $\mathrm{pH}$ values below 7.4, the $\log \left(K_{\mathrm{m}}\right)$ vs. pH plot of the WT enzyme does not change appreciably, while the H178A enzyme exhibits a slight decrease in $K_{\mathrm{m}}$ with increasing acidity $(\mathrm{pH}<7.2)$. These data suggest a small build up of hydronium ions may occur in place of H178 which, in turn, may stabilize substrate binding. Alternatively, the lack of the imidazole may cause greater steric freedom and thus a better fit for substrate. The slight increase in $K_{\mathrm{m}}$ observed for MP- $p$-NA may be due to a decrease in van der Waals interactions with the cyclic portion of the proline residue of the substrate and suggests that H178A may affect the way certain substrates bind to the $E c$ MetAP-I active site. The inflection on the basic side of the $\log \left(K_{\mathrm{m}}\right)$ vs. pH plot for WT EcMetAP-I at pH 7.9 is likely due to an ionization on the enzyme since there are no other ionizable groups with reasonable $\mathrm{p} K_{\mathrm{a}}^{\prime} \mathrm{s}$ on the substrate. Protonation of this groupfacilitates better binding of the substrate as shown in Scheme 1.

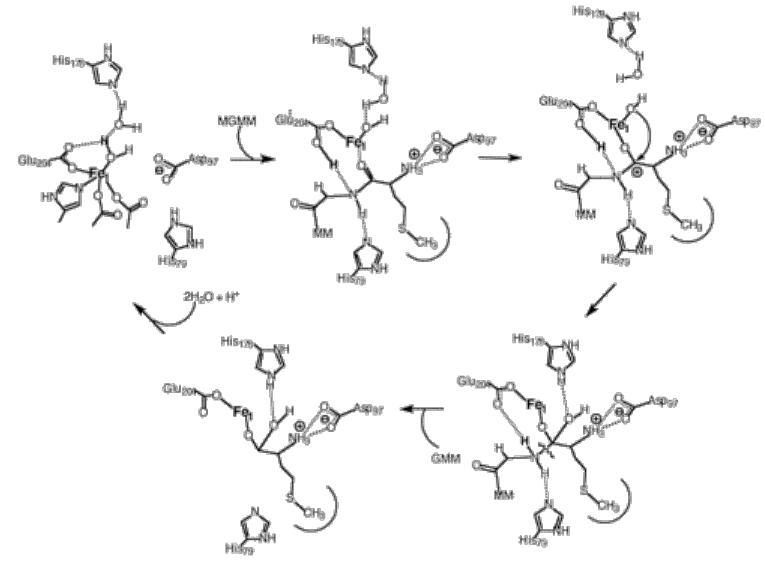

Figure 8 Proposed Catalytic Mechanism for EcMetAP-I.

A plot of $\log \left(k_{\text {cat }}\right)$ vs. pH for WT EcMetAP-I is bell-shaped, while the same plot for H178A shows increasing $k_{\text {cat }}$ as the $\mathrm{pH}$ is increased up to $\mathrm{pH}$ 7.8. Fits of $\log \left(k_{\mathrm{cat}}\right)$ vs $\mathrm{pH}$ to eq 4 provides values for $\mathrm{p} K_{\mathrm{ES} 1}$ of 7.2 and $\mathrm{p} K_{\mathrm{ES} 2}$ of 7.7 for WT $E c$ MetAP-I where the asymptotes meet the theoretical maximum $k_{\text {cat }}\left(k_{\text {cat }}^{\prime}\right)$ (Figure 4B). These data were also fit to eq 10, which is used when the $\mathrm{p} K$ 's are separated by less than 0.6 $\mathrm{pH}$ units, and provided values of $\mathrm{p} K_{\mathrm{ES} 1}=\mathrm{p} K_{\mathrm{ES} 2}=7.5$. These data indicate that one ionizable group $\left(\mathrm{p} K_{\mathrm{ES} 1}\right)$ must be deprotonated while a second ionizable group must be in the protonated form ( $\left.\mathrm{p} K_{\mathrm{ES} 2}\right)$ in the ES complex for catalysis to occur. The slopes of the asymptotes calculated as prescribed ( $\underline{37})$ for the acidic and basic limbs of $\log \left(k_{\text {cat }}\right)$ vs. pH for WT $E c$ MetAP-I indicate that one group is ionized on each limb. Because plots of $\log \left(k_{\text {cat }}\right)$ vs pH for both WT and H178A EcMetAP-I are identical within error, H178 is not the general base in catalysis.

Enzyme centered ionizable groups were gleaned from plots of $\log \left(k_{\text {cat }} / K_{\mathrm{m}}\right)$ vs pH since it is possible to determine $\mathrm{p} K$ values centered on the free enzyme and free substrate $(\underline{36})$. Similar to the plots of $\log \left(k_{\mathrm{cat}}\right)$ vs pH for WT and H178A $E c$ MetAP-I, plots of $\log \left(k_{\text {cat }} / K_{\mathrm{m}}\right)$ vs pH are bell-shaped for both WT $E c$ MetAP-I and $\mathrm{H} 178 \mathrm{~A}$. Fits of $\log \left(k_{\text {cat }} / K_{\mathrm{m}}\right)$ vs $\mathrm{pH}$ for WT $E c$ MetAP-I to eq 5 provides two ionizations values with $\mathrm{p} K_{\mathrm{E} 1}=7.7$ 
and $\mathrm{p} K_{\mathrm{E} 2}=6.6$. Both asymptotes have slopes of $\sim 1$ indicating a single ionizable group exists at both high and low $\mathrm{pH}$. The large difference between the $k_{\text {cat }}^{\prime} / k_{\mathrm{m}}^{\prime}$ and the apparent $k_{\text {cat }} / K_{\mathrm{m}}$ results in $\mathrm{p} K_{\mathrm{E} 1}$ being greater than $\mathrm{p} K_{\mathrm{E} 2}$. Since the $\mathrm{p} K$ values are separated by less than $0.6 \mathrm{pH}$ units, these data were fit to eq 11 $(\underline{39})$ and yield $\mathrm{p} K$ values of $\mathrm{p} K_{\mathrm{E} 1}=\mathrm{p} K_{\mathrm{E} 2}=7.1$. The existence of two ionizations indicates that there should be three different ionization states of the enzyme that affect catalytic efficiency (Scheme 1). Moreover, one of these ionizations may reflect proton dissociation from the substrate since $\mathrm{p} K_{\mathrm{s}}$ is in the $\mathrm{pH}$ range studied. Possible active site residues in EcMetAP-I that account for the enzyme-centered $\mathrm{p} K$ might include $\mathrm{H} 79$ or E204. $\mathrm{H} 79$ resides $\sim 5 \AA$ from Co1 while E204 is a ligand to Co1 and also forms an hydrogen bond to the metal bound water molecule.

Since $\mathrm{p} K_{\mathrm{E} 1}$ and $\mathrm{p} K_{\mathrm{E} 2}$ are not well separated for both WT and H178A EcMetAP-I, the associated error is rather high. Therefore, an alternative method was utilized to directly measure a metal centered deprotonation. Electronic absorption spectra of Co(II)-loaded WT and H178A EcMetAP-I were recorded as a function of $\mathrm{pH}$ between 6.0 and 9.0. Increasing the $\mathrm{pH}$ from 7.5 to 9.0 increases the molar absorptivity at $640 \mathrm{~nm}\left(\lambda_{\max }\right)$ from 135 to $290 \mathrm{M}^{-1} \mathrm{~cm}^{-1}$, while decreasing the $\mathrm{pH}$ from 7.5 to 6.5 decreases the molar absorptivity from 135 to $50 \mathrm{M}^{-1} \mathrm{~cm}^{-1}$. The range of observed molar absorptivity values as a function of $\mathrm{pH}$ is consistent with the $\mathrm{Co}(\mathrm{II})$ remaining five-coordinate at all $\mathrm{pH}$ values studied $(\underline{42})$. A plot of molar absorptivity $(\varepsilon)$ of the $\lambda_{\max }$ value at $640 \mathrm{~nm}$ vs. $\mathrm{pH}$ provides a simple sigmoidal curve with an apparent $\mathrm{p} K_{\mathrm{a}}$ value of 8.1. Since four ligating atoms are provided by enzyme amino acid groups, the fifth Co(II)-ligand must be a water molecule that is deprotonated to an hydroxide with a $\mathrm{p} K_{\mathrm{a}}$ value around 8.1. This water/hydroxide likely functions as the nucleophile during catalytic turnover. We have also recorded the electronic absorption spectrum of $\mathrm{H} 178 \mathrm{~A}$ as a function of $\mathrm{pH}$ and found a $\mathrm{p} K_{\mathrm{a}}$ value of $\sim 7.6$ based on a plot of molar absorptivity at $640 \mathrm{~nm}$ vs pH. Comparison of these data with those obtained for WT EcMetAP-I indicates that the $\mathrm{p} K_{\mathrm{a}}$ of the water/hydroxide bound to the Co(II) ion becomes more acidic by $0.5 \mathrm{pH}$ units when $\mathrm{H} 178$ is altered to an Ala residue.

Combination of these data suggests that $\mathrm{p} K_{\mathrm{E} 1}(7.8)$, determined from the $\log \left(k_{\mathrm{cat}} / K_{\mathrm{m}}\right) \mathrm{vs} \mathrm{pH}$ plot, matches within error the $\mathrm{p} K_{\mathrm{E}}$ (8.1) obtained from measurements of the $\mathrm{pH}$ dependent changes in UV-vis spectra of Co(II) EcMetAP-I. Therefore, this $\mathrm{p} K$ was assigned to the ionization of the metal-bound water molecule. On the basis of X-ray crystallography, H178 forms a hydrogen bond with a water molecule that, in turn, hydrogen bonds to the water molecule that bridges between the two Co(II) ions providing a $\mathrm{H} 178-\mathrm{H}_{2} \mathrm{O}-\mathrm{H}_{2} \mathrm{O}-\mathrm{Co}(\mathrm{II})$ proton relay system ( $\left.\underline{43}\right)$. It appears that $\mathrm{H} 178$ indirectly stabilizes the metalbound water molecule and helps to increase the $\mathrm{p} K_{\mathrm{a}}$ value relative to that in the H178A mutant. This change in $\mathrm{p} K_{\mathrm{a}}$ is critical for catalysis, since a metal-bound hydroxide would decrease the Lewis acidity of the divalent metal ion vs a metal-bound water molecule, thus reducing the ability of the carbonyl oxygen to bind to the metal ion and be activated.

On the basis of all of the kinetic, spectroscopic, and X-ray crystallographic data reported to date, an altered mechanism of action for EcMetAP-I is proposed (Figure 8) (21). Since both EcMetAP-I and PfMetAP-II have been shown to be fully active with only a single divalent metal ion present and additional divalent metal ions are inhibitory, MetAPs have been reclassified, by one of us, as mononuclear metalloproteases ( $\underline{23})$. At the same time, the crystal structure of EcMetAP-I and the close relatives including PfMetAP-II, $H s$ MetAP-II, and aminopeptidase $P$ show two metal ions in the active site ( $\underline{44})$. The catalytically active metal ion in EcMetAP-I is coordinated by $\mathrm{H} 171(\underline{23}, 25)$. On the basis of the recently proposed mechanism for the leucine aminopeptidase from Aeromonas proteolytica (45), the first step in catalysis for MetAPs is likely recognition of the N-terminal methionine side chain by the hydrophobic pocket adjacent to the metalloactive site $(\underline{21}, 43)$. Next, the peptide carbonyl oxygen coordinates to the histidine-ligated divalent metal ion. Hydrogen bond formation between His79 and the backbone $\mathrm{N}-\mathrm{H}$ scissile peptide bond has been proposed based on X-ray crystallographic results, thereby stabilizing the leaving group $(\underline{21}, 43)$. In addition, Glu204, which is also a ligand to the histidine-containing divalent metal ion, was proposed to be a proton acceptor/donor in the catalytic process $(\underline{21,43})$. This assignment is consistent with the observed $\mathrm{p} K_{\mathrm{ES} 1}$ of 7.2 for the hydrogen bound Glu204 deprotonation process. Since the N-terminal amine nitrogen of the substrate forms a hydrogen bond with D97 based on X-ray crystallography, in the absence of a second 
metal ion D97 likely assists to position the substrate properly in the active site for formation of the transition-state intermediate. This proposal is based on the fact that protonated MGMM binds more tightly to EcMetAP-I as well as the crystal structure of EcMetAP-I with a substrate analogue inhibitor in which the $\mathrm{N}$-terminal amine nitrogen is coordinated to the second Co(II) ion and forms hydrogen bonds to D97. Assignment of $\mathrm{p} K_{\mathrm{E} 2}(7.9)$ to $\mathrm{H79}$, based on the plot of $\log K_{\mathrm{m}} \mathrm{vs} \mathrm{pH}$, is likely since $\mathrm{H} 79$ forms a hydrogen bond to the backbone amine nitrogen of the substrate, based on X-ray crystallography. Next, the productforming $\mathrm{C}-\mathrm{N}$ bond-breaking step occurs followed by the release of the cleaved peptide. Finally, the active site adds two water molecules: one that binds to the divalent metal ion and one that bridges between the coordinated water molecule and H178. Therefore, $\mathrm{H} 178$ helps to regulate the $\mathrm{p} K_{\mathrm{a}}$ of the metal bound nucleophile, but does not function as the active site general acid/base.

In summary, the new data provide support for the key elements of the previously proposed mechanism $(\underline{21})$ and suggest that a similar mechanism can apply to the enzyme with a single metal ion bound in the active site.

\section{References}

1 Bradshaw, R. A. (1989) Trends Biochem. Sci.14, 276-279.

$\underline{2}$ Meinnel, T., Mechulam, Y., and Blanquet, S. (1993)Biochimie75, 1061-1075.

$\underline{3}$ Bradshaw, R. A., Brickey, W. W., and Walker, K. W. (1998) Trends Biochem. Sci.23, 263-267.

4 Arfin, S. M., and Bradshaw, R. A. (1988) Biochemistry27, 7979-7984.

$\underline{5}$ Hirel, P.-H., Schmitter, J.-M., Dessen, P., Fayat, G., and Blanquet, S. (1989) Proc. Natl. Acad. Sci. U.S.A.86, 8247-8251.

$\underline{6}$ Ben-Bassat, A., and Bauer, K. (1987) Nature326, 315.

$\underline{7}$ Tobias, J. W., Shrader, T. E., Rocap, G., and Varshavsky, A. (1991) Science254, 1374-1377.

$\underline{8}$ Chang, S.-Y. P., McGary, E. C., and Chang, S. (1989)J. Bacteriol.171, 4071-4072.

$\underline{9}$ Chang, Y.-H., Teichert, U., and Smith, J. A. (1992) J. Biol. Chem.267, 8007-8011.

10. Li, X., and Chang, Y.-H. (1995) Proc. Natl. Acad. Sci. U.S.A.92, 12357-12361.

11 Miller, C. G., Kukral, A. M., Miller, J. L., and Movva, N. R. (1989) J. Bacteriol.171, 5215-5217.

12 Taunton, J. (1997) Chem. Biol.4, 493-496.

13 Griffith, E. C., Su, Z., Turk, B. E., Chen, S., Chang, Y.-H., Wu, Z., Biemann, K., and Liu, J. O. (1997) Chem. Biol.4, 461-471.

14 Sin, N., Meng, L., Wang, M. Q., Wen, J. J., Bornmann, W. G., and Crews, C. M. (1997) Proc. Natl. Acad. Sci. U.S.A.94, 6099-6103.

15 Lowther, W. T., McMillen, D. A., Orville, A. M., and Matthews, B. W. (1998) Proc. Natl. Acad. Sci. U.S.A.95, $12153-12157$.

16 Liu, S., Widom, J., Kemp, C. W., Crews, C. M., and Clardy, J. (1998) Science282, 1324-1327.

17 Miller, C. G., Strauch, K. L., Kukral, A. M., Miller, J. L., Wingfield, P. T., Mazzei, G. J., Werlen, R. C., Graber, P., and Movva, N. R. (1987) Proc. Natl. Acad. Sci. U.S.A.84, 2718-2722.

18 Tahirov, T. H., Oki, H., Tsukihara, T., Ogasahara, K., Yutani, K., Ogata, K., Izu, Y., Tsunasawa, S., and Kato, I. (1998) J. Mol. Biol.284, 101-124.

19 Roderick, S. L., and Matthews, B. W. (1993) Biochemistry32, 3907-3912.

20. Lowther, W. T., Orville, A. M., Madden, D. T., Lim, S., Rich, D. H., and Matthews, B. W. (1999) Biochemistry38, 7678-7688.

21 Lowther, T. W., Zhang, Y., Sampson, P. B., Honek, J. F., and Matthews, B. W. (1999) Biochemistry38, $14810-14819$.

22 D'souza, V. M., and Holz, R. C. (1999) Biochemistry38, 11079-11085.

23 D’souza, V. M., Bennett, B., Copik, A. J., and Holz, R. C. (2000) Biochemistry39, 3817-3826.

24 Meng, L., Ruebush, S., D'Souza V, M., Copik, A. J., Tsunasawa, S., and Holz, R. C. (2002) Biochemistry41, 7199-208.

$\underline{25}$ Cosper, N. J., D'souza, V., Scott, R., and Holz, R. C. (2001) Biochemistry40, 13302-13309.

26 Matthews, B. W. (1988) Acc. Chem. Res.21, 333-340. 
27 Vallee, B. L., and Auld, D. S. (1993) Proc. Natl. Acad. Sci. U.S.A.90, 2715-2718.

28 Vallee, B. L., and Galdes, A. (1984) Adv. Enzymol.56, 283-430.

$\underline{29}$ Vallee, B. L., and Auld, D. S. (1990) Biochemistry29, 5647-5659.

30. Christianson, D. W., and Lipscomb, W. N. (1989) Acc. Chem. Res.22, 62-69.

31 Lowther, W. T., and Matthews, B. W. (2000) Biochim. Biophys. Acta1477, 157-67.

$\underline{32}$ Zhou, Y., Gou, X.-C., Yi, T., Yoshimoto, T., and Pei, D. (2000) Anal. Biochem.280, 159-165.

33 Winzor, D. J., and Sawyer, W. H. (1995) Quantitative Characterization of Ligand Binding, Wiley-Liss, New York.

34 Segel, I. H. (1975) Enzyme Kinetics: Behavior and Analysis of Rapid Equilibrium and Steady-State Enzyme Systems, 1st ed., John Wiley \& Sons, New York.

$\underline{35}$ Cornish-Bowden, A. (1995) Fundamentals of Enzyme Kinetics, Portland Press Ltd., London.

36 Dixon, M., and Webb, E. C. (1979) Enzymes, 3rd ed., Academic Press, New York.

37 Cleland, W. W. (1997) Adv. Enzymol. Relat. Areas Mol. Biol.45, 273-387.

$\underline{38}$ Tipton, K. F., and Dixon, H. B. (1997) Methods Enzymol.63, 183-234.

$\underline{39}$ Cleland, W. W. (2003), personal communication.

40. Strzelczak, G., Bobrowski, K., and Holcman, J. (1998) Radiat. Res.150, 688-694.

$\underline{41}$ Baker, J. O., and Prescott, J. M. (1983) Biochemistry22, 5322-5331.

$\underline{42}$ Bertini, I., and Luchinat, C. (1984) in Adv. Inorg. Biochem. (Eichhorn, G. L., and Marzilli, L. G., Eds.) pp 71-111, Elsevier, New York.

43 Lowther, W. T., Orville, A. M., Madden, D. T., Lim, S., Rich, D. H., and Matthews, B. W. (1999) Biochemistry38, 7678-7688.

44 Lowther, W. T., and Matthews, B. W. (2000)Biochim. Biophys. Acta1477, 157-167.

45 Ustynyuk, L., Bennett, B., Edwards, T., and Holz, R. C. (1999) Biochemistry38, 11433-11439.

1 Abbreviations: EcMetAP-I (methionyl aminopeptidase from E. coli); PfMetAP-II (methionyl aminopeptidase from Pyrococcus furiosus); HsMetAP-II (human methionyl aminopeptidase); HEPES ([4-(2-hydroxyethyl)-1-piperazineethanesulfonic acid]); MES ([2-( $N$ -

morpholino)ethanesulfonic acid]); EPPS ( $N$-2-hydroxyethylpiperazinepropane sulfonic acid); Tricine ( $N$-tris[hydroxymethyl]methylglycine; ICP-AES (inductively coupled plasma-atomic emission spectroscopy); AAP (aminopeptidase fromAeromonas proteolytica); blLAP (bovine lens leucine aminopeptidase); WT (wild-type); ITC (isothermal titration calorimetry); MGMM (Met-Gly-Met-Met); MP- $p$-NA (Met-Pro- $p$-nitroanilide); Nle-AAEE (norleucine-Ala-Ala-Glu-Glu). 